\title{
KARAKTERISTIK DEMOGRAFI, SOSIAL, DAN EKONOMI KELUARGA PENERIMA PROGRAM KELUARGA HARAPAN (PKH)
}

\author{
Characteristics of Demographic, Social, and Economic of \\ Cash Conditional Transfer (PKH) Recipients \\ Megawati Simanjuntak $^{1^{*}}$, Herien Puspitawati $^{1}$, MD Djamaludin $^{1}$ \\ ${ }^{1}$ Staf Pengajar Departemen Ilmu Keluarga dan Konsumen, Fakultas Ekologi Manusia, \\ Institut Pertanian Bogor, Jalan Lingkar Kampus IPB Dramaga, \\ Bogor 16680
}

\begin{abstract}
Cash Conditional Transfer (PKH) is one of the government's efforts to reduce poverty and to improve the quality of human resources in poor communities through the provision of conditional subsidies. The purpose of this study were to identify characteristics of demographic, social, and economic of PKH recipient families and to analyze the differences of economic characteristics between pre and during families get PKH funds. This study applied a combination of cross-sectional and retrospective designs. Data collection located in eight villages in Dramaga District, Bogor Regency from March to December 2009. The samples were the wives from the families who received $\mathrm{PKH}$ as many as 150 people determined randomly by systematic methods. Statistical analyses were descriptive and paired t-test. Characteristics of demographic, social and economics of samples concluded from this study were the largest percentage of families ranged from five to six family member from nuclear families, as well as head of family and wife age ranged from 30 to 49 years. Their education levels were only up to primary school with head of family worked as laborers, while most wives did not work. Most family heads and wives both literacy in reading and writing Latin alphabet. Family total revenue increased significantly 1.3 fold during received PKH fund. Categories poverty did not change for the families who received $P K H$, but the ownership of electronic devices increased. Head of family has the largest and significant contribution to the total revenue of the family. The average expenditure per month for food and non-food respectively 70,1\% and $29,9 \%$. Family debt significantly increased nearly twice as families received $P K H$ fund. Ability to pay debt with assets owned, increased by obtaining PKH fund.
\end{abstract}

Key words: cash conditional transfer, demographic, economic, social

\section{PENDAHULUAN}

Kemiskinan merupakan masalah multidimensi yang ditandai oleh rendahnya rata-rata kualitas hidup penduduk, pendidikan, kesehatan, gizi anak-anak, dan sumber air minum. Beban kemiskinan sangat dirasakan oleh kelompok-kelompok tertentu seperti perempuan dan anak-anak yang berakibat pada terancamnya masa depan oleh karena kekurangan gizi, serta rendahnya tingkat kesehatan dan pendidikan. Berdasarkan laporan UNDP (United Nations Development Programme) nilai HDI Indonesia antara tahun 1980 dan 2007 meningkat $1,26 \%$ per tahun dari $0,522(1980)$ menjadi 0,734 (2007) (UNDP 2009).
Jumlah penduduk miskin di Indonesia pada bulan Maret 2009 sebesar 32,53 juta $(14,2 \%)$, dibandingkan dengan penduduk miskin pada bulan Maret 2008 yang berjumlah 34,96 juta $(15,4 \%)$. Hal ini menunjukkan jumlah penduduk miskin dari tahun 2008-2009 turun sebesar 2,43 juta (BPS 2009).

Menurut Salim (1980) dalam Dharmawan et al. (2009) penduduk miskin dapat dicirikan dengan: (1) rata-rata tidak mempunyai faktor produksi sendiri seperti tanah, modal, peralatan kerja, dan keterampilan; (2) mempunyai tingkat pendidikan yang rendah; (3) kebanyakan bekerja atau berusaha sendiri dan bersifat usaha kecil (sektor informal), setengah menganggur atau menganggur (tidak bekerja); 
kebanyakan berada di perdesaan atau daerah tertentu perkotaan (slum area); dan (5) kurangnya kesempatan untuk memperoleh (dalam jumlah yang cukup) bahan kebutuhan pokok pakaian, perumahan, fasilitas kesehatan, air minum, pendidikan, angkutan, fasilitas komunikasi, dan kesejahteraan sosial lainnya.

Program Keluarga Harapan (PKH) atau Cash Conditional Transfer (CCT) merupakan salah satu upaya pemerintah untuk meningkatkan kualitas manusia Indonesia dengan mengkampanyekan pembangunan manusia Indonesia untuk meningkatkan pelayanan dasar kepada masyarakat melalui program pemberian subsidi bersyarat. Tujuan utama dari $\mathrm{PKH}$ adalah untuk mengurangi kemiskinan dan meningkatkan kualitas sumberdaya manusia terutama pada kelompok masyarakat miskin. Tujuan tersebut sekaligus sebagai upaya mempercepat pencapaian target Millenium Development Goals (MDGs) tahun 2015.

Dengan pertimbangan bahwa sasaran $\mathrm{PKH}$ adalah Rumah Tangga Sangat Miskin (RTSM) dirasakan perlu untuk mengkaji berbagai karakteristik keluarga penerima $\mathrm{PKH}$ yang mencakup demografi, sosial, dan ekonomi. Hal ini perlu dilakukan mengingat program ini direncanakan akan berlanjut hingga tahun 2015. Data ini diharapkan dapat menjadi data baseline untuk penelitian-penelitian selanjutnya terkait dengan $\mathrm{PKH}$. Pengkajian juga dilakukan untuk melihat apakah ada perbedaan karakteristik ekonomi antara pra dan saat keluarga memperoleh dana PKH.

Secara khusus, tujuan penelitian ini adalah untuk mengidentifikasi karakteristik demografi, sosial, dan ekonomi keluarga penerima, dan menganalisis perbedaan karakteristik ekonomi antara pra dan saat keluarga mendapat dana $\mathrm{PKH}$.

\section{METODE}

\section{Desain, Lokasi, dan Waktu}

Studi ini menerapkan kombinasi desain cross-sectional dan retrospektif karena juga ingin menganalisis perbedaan karakteristik ekonomi keluarga antara pra dan saat menerima dana $\mathrm{PKH}$. Lokasi penelitian adalah di delapan desa di Kecamatan Dramaga, Kabupaten Bogor dengan waktu penelitian selama enam bulan, yakni dari bulan Maret hingga Desember 2009. Penelitian ini merupakan bagian dari penelitian payung yang berjudul "Faktor-
Faktor yang Mempengaruhi Kesejahteraan Keluarga dan Prestasi Belajar Anak pada Keluarga Penerima Program Keluarga Harapan (PKH)".

\section{Teknik Penarikan Contoh}

Populasi penelitian ini adalah seluruh keluarga yang mempunyai anak usia sekolah dalam keluarga penerima $\mathrm{PKH}$ di Kecamatan Dramaga dengan mengacu pada penelitian payung. Target penelitian adalah istri/ibu pada keluarga penerima Program Keluarga Harapan. Penentuan contoh dilakukan secara acak sistematik yang menghasilkan 150 responden.

\section{Jenis dan Teknik Pengumpulan Data}

Jenis data yang dikumpulkan dalam penelitian ini adalah karakteristik demografi (besar dan struktur keluarga, usia kepala keluarga dan istri), karakteristik sosial (tingkat pendidikan kepala keluarga dan istri, kemampuan baca dan tulis latin serta bantuan yang diterima di luar $\mathrm{PKH}$ ) dan karakteristik ekonomi (pekerjaan kepala keluarga dan istri, kepemilikan aset, rasio hutang dan aset, penerimaan total keluarga, pengeluaran keluarga, dan kontributor terhadap penerimaan keluarga). Pengumpulan data dilakukan secara wawancara langsung menggunakan kuesioner dan indepth interview.

\section{Pengolahan dan Analisis Data}

Pengolahan data dilakukan dengan menggunakan Microsoft Excel dan SPSS for Windows. Pengolahan data dibagi menjadi dua, yakni statistika deskriptif dan statistika induktif (inferensial). Data disajikan dalam bentuk tabel. Analisis statistik yang digunakan adalah Paired Samples T-Test.

\section{HASIL DAN PEMBAHASAN}

\section{Karakteristik Demografi Keluarga}

Besar dan Struktur Keluarga. Besar keluarga contoh dalam penelitian ini dapat dikelompokkan menjadi tiga seperti yang disajikan pada Tabel 1. Mengacu pada penetapan BKKBN, yang disebut keluarga kecil adalah yang memiliki anggota keluarga kurang dari dan sama dengan 4 orang, lainnya disebut keluarga sedang (5-6 orang), dan keluarga besar (>6 orang). Hasil penelitian menunjukkan bahwa $22 \%$ termasuk keluarga kecil, $58 \%$ termasuk keluarga sedang, dan $20 \%$ termasuk keluarga besar. Jika dikaitkan dengan hasil 
studi Widyanti et al. (2009) ada indikasi bahwa semakin besar keluarga, maka semakin besar peluang keluarga mengalami kemiskinan kronis. Tidak dapat dipungkiri bahwa beban keluarga yang semakin besar mengharuskan keluarga memiliki sumberdaya yang semakin besar pula, padahal dalam keluarga penerima $\mathrm{PKH}$ yang terkategori miskin, sumberdaya sangat minim.

Jika dilihat berdasarkan struktur keluarga, maka sebagian besar (84\%) keluarga contoh termasuk ke dalam keluarga inti, artinya keluarga terdiri dari kepala keluarga, istri, dan anak. Sisanya adalah keluarga luas dimana di dalam keluarga contoh tinggal pula nenek, keponakan atau kerabat keluarga luas lainnya (Tabel 1).

Tabel 1. Sebaran dan statistik besar dan struktur keluarga

\begin{tabular}{|c|c|c|c|}
\hline No & $\begin{array}{c}\text { Kategori Besar dan } \\
\text { Struktur Keluarga }\end{array}$ & $\begin{array}{c}\text { Jumlah } \\
(\mathrm{n})\end{array}$ & $\begin{array}{c}\text { Persentase } \\
(\%)\end{array}$ \\
\hline \multicolumn{4}{|c|}{ Kategori Besar Keluarga(n=150) } \\
\hline 1. & $\leq 4$ orang & 33 & 22,0 \\
\hline 2. & $5-7$ orang & 87 & 58,0 \\
\hline & $>7$ orang & 30 & 20,0 \\
\hline & Rata-Rata $\pm S D$ & \multicolumn{2}{|c|}{$6,03 \pm 1,87$} \\
\hline & isaran (min-max) & \multicolumn{2}{|c|}{$3-13$} \\
\hline \multicolumn{4}{|c|}{ Struktur Keluarga(n=150) } \\
\hline 1. & Keluarga Inti & 126 & 84,0 \\
\hline 2. & Keluarga Luas & 24 & 16,0 \\
\hline
\end{tabular}

Usia Kepala Keluarga dan Istri. Secara keseluruhan usia kepala keluarga dan istri pada penelitian ini paling banyak terdapat pada kisaran antara 30 sampai 49 tahun yang bila didasarkan pada kelompok usia produktif, yaitu mulai usia 15 tahun sampai dengan usia 64 tahun, maka dapat dikatakan bahwa sebagian besar contoh berada pada kelompok usia produktif (Tabel 2). Rata-rata usia kepala keluarga adalah 44,59 tahun, sedangkan usia istri rata-rata 38,41 tahun dengan perbedaan yang nyata $(p=0,000)$ antara keduanya. Kategori usia tersebut masih termasuk produktif sehingga potensi untuk melakukan aktivitas ekonomi dalam rangka meningkatkan kesejahteraan keluarga masih relatif tinggi.

Berdasarkan sebaran usia, dapat digambarkan bahwa sebagian besar keluarga contoh adalah keluarga dengan anak usia sekolah yang sedang tumbuh dan berkembang, dalam artian bahwa kebutuhan keluarga pada saat ini cukup besar dan keluarga-keluarga ini memerlukan pengelolaan sumberdaya keluarga yang tepat untuk memenuhi kebutuhan keluarga yang semakin bertambah. Hal ini cukup didukung oleh usia suami yang sebagian besar sudah mencapai usia yang matang berkaitan dengan pengalaman hidup maupun di bidang pekerjaan. Begitu pula dengan sebaran usia istri yang cukup mendukung untuk melakukan kegiatan produktif karena pada dasarnya usia produktif bagi seorang perempuan berada pada usia 25-55 tahun. Semakin bertambah usia perempuan semakin berkurang jumlah tenaga yang dapat dimanfaatkan untuk kegiatan produktif sesuai dengan semakin lemahnya kondisi fisik.

Tabel 2. Sebaran dan statistik usia kepala keluarga dan istri

\begin{tabular}{|c|c|c|c|c|}
\hline \multirow[t]{2}{*}{$\begin{array}{l}\text { Kategori Usia } \\
\text { (tahun) }\end{array}$} & \multicolumn{2}{|c|}{$\begin{array}{l}\text { Kepala } \\
\text { Keluarga } \\
(n=133)^{1}\end{array}$} & \multicolumn{2}{|c|}{$\begin{array}{c}\text { Istri } \\
(n=149)^{2}\end{array}$} \\
\hline & $n$ & $\%$ & $\mathbf{n}$ & $\%$ \\
\hline$<25$ & 1 & 0,8 & 1 & 0,7 \\
\hline $25-29$ & 3 & 2,3 & 15 & 10,1 \\
\hline $30-39$ & 47 & 35,3 & 71 & 47,7 \\
\hline $40-49$ & 46 & 34,6 & 43 & 28,9 \\
\hline $50-59$ & 23 & 17,3 & 19 & 12,8 \\
\hline$>60$ & 13 & 9,8 & 0 & 0,0 \\
\hline Rata-rata $\pm S D$ & \multicolumn{2}{|c|}{$44,59 \pm 10,21$} & \multicolumn{2}{|c|}{$38,41 \pm 8,11$} \\
\hline Kisaran (min-max) & \multicolumn{2}{|c|}{$24-85$} & \multicolumn{2}{|c|}{$18-58$} \\
\hline $\begin{array}{c}\text { Uji Beda } \\
\text { Berpasangan (sig) }\end{array}$ & \multicolumn{4}{|c|}{$0,000^{* *}$} \\
\hline \multicolumn{5}{|c|}{$\begin{array}{l}\text { Ket: }{ }^{1} \text { Meninggal/Pisah sebanyak } 17 \text { orang (kepala } \\
\text { keluarga); } \\
{ }^{2} \text { istri pisah sebanyak } 1 \text { orang } \\
{ }^{* *} \text { Nyata pada } p<0,01\end{array}$} \\
\hline
\end{tabular}

\section{Karakteristik Sosial Keluarga}

Tingkat Pendidikan Kepala Keluarga

dan Istri. Tingkat pendidikan kepala keluarga dan istri baik secara formal maupun nonformal akan berpengaruh terhadap cara dan pola pikir untuk dapat memenuhi kebutuhan hidup dengan kondisi sosial ekonomi yang tidak memungkinkan. Menurut Gunarsa dan Gunarsa (2008), tingkat pendidikan orangtua baik secara langsung maupun tidak langsung akan mempengaruhi komunikasi antara orangtua dan anak di dalam lingkungan keluarga. Data hasil penelitian yang dapat dilihat pada Tabel 3 menunjukkan bahwa tingkat pendidikan formal yang pernah ditempuh mayoritas kepala keluarga adalah tamat SD, dengan persentase sebesar $48,1 \%$. Di lain pihak, istri bahkan mempunyai tingkat pendidikan yang lebih rendah dari kepala keluarga, yakni lebih dari separuhnya $(59,1 \%)$ adalah tidak tamat SD. Jika dikategorikan berdasarkan lamanya pendidikan yang ditempuh oleh kepala keluarga dan istri, maka sebagian besar $(88 \%)$ kepala keluarga dan hampir semua $(98,7 \%)$ istri adalah berpendidikan $\leq 9$ tahun, sedangkan sisanya adalah berpendidikan 
lebih dari 9 tahun. Hasil analisis uji beda secara statistik ditemukan perbedaan yang nyata $(p=0,000)$ antara pendidikan kepala keluarga dan istri, dengan lamanya pendidikan kepala keluarga lebih tinggi daripada pendidikan istri.

Tabel 3. Sebaran dan statistik tingkat pendidikan kepala keluarga dan istri

\begin{tabular}{|c|c|c|c|c|}
\hline \multirow[t]{2}{*}{ Tingkat Pendidikan } & \multicolumn{2}{|c|}{$\begin{array}{c}\text { Kepala } \\
\text { Keluarga } \\
(n=133)^{1}\end{array}$} & \multicolumn{2}{|c|}{$\begin{array}{c}\text { Istri } \\
(n=149)^{2}\end{array}$} \\
\hline & $n$ & $\%$ & $n$ & $\%$ \\
\hline Tidak tamat SD & 51 & 38,3 & 88 & 59,1 \\
\hline Tamat SD & 64 & 48,1 & 39 & 26,2 \\
\hline Tamat SMP & 8 & 6,0 & 3 & 2,0 \\
\hline Tamat SLTA & 1 & 0,8 & 1 & 0,7 \\
\hline Tidak pernah sekolah & 9 & 6,8 & 18 & 12,1 \\
\hline Rata-rata $\pm S D$ (tahun) & \multicolumn{2}{|c|}{$4,83 \pm 2,26$} & \multicolumn{2}{|c|}{$3,76 \pm 2,26$} \\
\hline $\begin{array}{c}\text { Kisaran (min-max) } \\
\text { (tahun) }\end{array}$ & \multicolumn{2}{|c|}{$0-12$} & \multicolumn{2}{|c|}{$0-12$} \\
\hline
\end{tabular}

Uji Beda Berpasangan 0,000**

Ket : ${ }^{1}$ Meninggal/Pisah sebanyak 17 orang (kepala keluarga);

${ }^{2}$ istri pisah sebanyak 1 orang

** Nyata pada $p<0,01$

Temuan pendidikan kepala keluarga dan istri contoh penelitian ini sejalan dengan data pada Website Resmi Kementerian Negara Pemberdayaan Perempuan dan Perlindungan Anak RI dimana data tahun 2007 saja menunjukkan bahwa rata-rata lama sekolah di Kabupaten Bogor untuk tahun 2007 untuk laki-laki adalah 8 tahun, sedangkan perempuan hanya 6,8 tahun. Rendahnya tingkat pendidikan masyarakat dapat mengakibatkan rendahnya tingkat kesejahteraan. Sebagaimana diketahui bahwa pendidikan yang tinggi merupakan sarana untuk menggapai hidup yang lebih berkualitas. Pendidikan yang tinggi akan memudahkan seseorang untuk mendapatkan pekerjaan yang layak dan memberikan penghasilan yang memadai.

Berdasarkan data pada Tabel 3 dapat pula disimpulkan bahwa pendidikan kepala keluarga lebih tinggi dibandingkan pendidikan istri, hal ini tidak berbeda dengan yang terjadi dalam masyarakat pada umumnya. Hal ini berkaitan dengan sarana pendidikan yang tersedia, di mana biasanya orangtua enggan bila anak perempuannya sekolah ke tempat yang jauh. Pendidikan akan menentukan jenis pekerjaan yang dilakukan oleh seseorang. Pendidikan berpengaruh terhadap tingkat pendapatan serta daya beli keluarga. Tingkat pendidikan seseorang juga akan mempengaruhi nilai- nilai yang dianutnya, cara berpikir, cara pandang, bahkan persepsinya terhadap suatu masalah. Bahkan hasil studi Widyanti et al. (2009) menunjukkan bahwa proporsi anggota keluarga berpendidikan SMA ke atas yang lebih tinggi akan menurunkan secara signifikan peluang keluarga menjadi miskin kronis atau rawan.

Kemampuan Baca Tulis Aksara Latin. Jika dilihat dari melek aksara baik dari membaca maupun menulis aksara latin ternyata lebih dari $85 \%$ kepala keluarga maupun istri termasuk mampu dalam kedua keterampilan tersebut (Tabel 4). Namun yang memprihatinkan adalah kemampuan membaca dan menulis aksara latin istri yang relatif lebih rendah dibandingkan kepala keluarga. Hal ini terlihat lebih dari dua kali lipat istri dibandingkan kepala keluarga yang tidak dapat membaca dan menulis aksara latin. Orangtua khususnya istri yang tidak mampu membaca dan menulis aksara latin merupakan faktor penghambat dalam menerapkan pola asuh belajar yang baik kepada anak.

Tabel 4. Sebaran contoh berdasarkan kemampuan baca dan tulis aksara latin kepala keluarga dan istri (persentase)

\begin{tabular}{|c|c|c|c|c|}
\hline \multirow{2}{*}{$\begin{array}{l}\text { Kemampuan } \\
\text { Baca Tulis } \\
\text { Aksara Latin }\end{array}$} & \multicolumn{2}{|c|}{$\begin{array}{c}\text { Kepala Keluarga } \\
(n=133)^{1}\end{array}$} & \multicolumn{2}{|c|}{ Istri $(n=149)^{2}$} \\
\hline & Baca & Tulis & Baca & Tulis \\
\hline Melek Aksara & 91,7 & 91,7 & 84,6 & 83,3 \\
\hline Buta Aksara & 8,3 & 8,3 & 15,4 & 16,8 \\
\hline
\end{tabular}

Penyebab buta huruf dapat diakibatkan faktor internal dan atau faktor eksternal individu yang bersangkutan. Faktor internal dapat disebabkan antara lain karena rendahnya motivasi yang bersangkutan maupun dukungan dari keluarganya untuk mengikuti pendidikan disamping kemampuan ekonomi keluarga yang tidak memadai. Sementara itu, faktor eksternal disebabkan antara lain karena penyebaran penduduk di daerah terpencil yang tidak merata, terisolasinya daerah terpencil dari informasi dan rendahnya aksesibilitas yang dibangun, serta belum optimalnya fungsi kelembagaan masyarakat dalam bidang pendidikan, karena kelembagaannya sendiri belum eksis selain terbatasnya jumlah dan distristrisi tutor, kesulitan untuk mengakses sarana pendidikan disamping masyarakat yang kurang mampu secara finansial. Dampak yang 
ditimbulkan oleh buta huruf antara lain akses untuk mendapatkan informasi pekerjaan menjadi sulit sehingga sulit pula untuk memperoleh pekerjaan. Bila memperoleh pekerjaan pun terbatas pada pekerjaan yang sifatnya fisik dengan upah yang rendah, dengan kata lain daya tawar masyarakat tersebut untuk memperoleh pekerjaan dan penghasilan yang layak menjadi rendah. Hal ini berpengaruh terhadap kemampuan daya beli masyarakat.

Bantuan yang Diterima di Luar PKH. Selain dana $\mathrm{PKH}$, keluarga contoh juga memperoleh bantuan berupa Beras Miskin (Raskin), Askeskin (Asuransi Kesehatan untuk Masyarakat Miskin)/Jamkesmas (Jaminan Kesehatan Masyarakat) atau BLT (Bantuan Langsung Tunai) (Tabel 5). Persentase keluarga yang mendapat raskin antara pra dan saat PKH adalah sama, yakni $98,7 \%$. Persentase keluarga yang mendapat Askeskin/Jamkesmas dan BLT mengalami penurunan, yakni dari masing-masing 60,7\% dan $90,7 \%$ praPKH menjadi $55,3 \%$ dan $88 \%$ saat $\mathrm{PKH}$.

Tabel 5. Sebaran contoh berdasarkan bantuan yang pernah diterima keluarga pra dan saat $\mathrm{PKH}$

\begin{tabular}{lcrrr}
\hline \multirow{2}{*}{$\begin{array}{c}\text { Bantuan yang } \\
\text { Diterima }\end{array}$} & \multicolumn{2}{c}{$\begin{array}{c}\text { PraPKH } \\
(\mathbf{n = 1 5 0 )}\end{array}$} & \multicolumn{2}{c}{$\begin{array}{c}\text { SaatPKH } \\
(\mathbf{n}=\mathbf{1 5 0})\end{array}$} \\
\cline { 2 - 5 } & Ya & Tidak & Ya & Tidak \\
\hline Raskin & 98,7 & 1,3 & 98,7 & 1,3 \\
Askeskin/Jamkesmas & 60,7 & 39,3 & 55,3 & 44,7 \\
BLT & 90,7 & 9,3 & 88,0 & 12,0 \\
\hline
\end{tabular}

Bantuan Langsung Tunai (BLT) adalah bantuan kepada rumah tangga miskin sebesar $\mathrm{Rp} 100.000,00$ per bulan yang diberikan tiga bulan sekali melalui PT. Pos Indonesia, dimana pola ini diadopsi oleh $\mathrm{PKH}$ dalam penentuan target dan cara penyalurannya. Askeskin/Jamkesmas merupakan program pelayanan kesehatan gratis bagi masyarakat miskin. Untuk penyakit-penyakit ringan biasanya masyarakat berobat di puskesmas yang tarifnya sangat murah (Rp 3.000,00 per sekali kunjungan) atau bidan/petugas kesehatan di desa yang juga tidak terlalu mahal. Namun, untuk penyakitpenyakit berat masyarakat harus berobat di rumah sakit yang biayanya mahal dan tidak terjangkau orang miskin. Keberadaan program Askeskin sangat membantu kelu- arga miskin untuk mengakses pelayanan kesehatan yang diperlukan.

Raskin merupakan pembagian beras bagi keluarga miskin dengan alokasi 15 kg/RTS (Rumah Tangga Sasaran) per bulan. Dalam implementasinya, keluarga contoh dapat secara bersamaan memper-oleh ketiga program tersebut ditambah dengan dana $\mathrm{PKH}$. Hal ini dimungkinkan karena PKH bukan merupakan kelanjutan program Subsidi Langsung Tunai yang diberikan dalam rangka membantu rumah tangga miskin mempertahankan daya belinya pada saat pemerintah melakukan penye-suaian harga BBM. Program Bantuan Langsung Tunai (BLT) dihentikan tahun 2010 setelah berjalan selama lima tahun. Hasil wawancara mendalam dengan contoh mengindikasikan bahwa $\mathrm{PKH}$ lebih disukai dibandingkan program lainnya karena jumlah dana yang diterima lebih besar.

\section{Karakteristik Ekonomi Keluarga}

Pekerjaan Kepala Keluarga dan Istri. Hasil penelitian menunjukkan bahwa pada praPKH kepala keluarga yang mempunyai pekerjaan utama adalah $96 \%$, yang mengalami penurunan menjadi $94,2 \%$ saat keluarga mendapat dana PKH. Namun untuk pekerjaan tambahan, mengalami peningkatan dari $10,8 \%$ praPKH menjadi $12,8 \%$ saat mendapat dana $\mathrm{PKH}$. Selanjutnya terdapat $4,3 \%$ kepala keluarga yang tidak bekerja praPKH, bahkan saat $\mathrm{PKH}$ persentasenya meningkat menjadi $6,1 \%$. Jenis pekerjaan utama terbanyak ditekuni oleh kepala keluarga adalah sebagai buruh, baik buruh nontani dan buruh tani yang sifatnya sporadis (Tabel 6). Jenis pekerjaan kepala keluarga terkait dengan rendahnya tingkat pendidikan rendah yang menimbulkan kesulitan mengakses pekerjaan-pekerjaan yang menuntut keterampilan atau pengetahuan.

Jenis pekerjaan sebagai buruh tergolong tidak tetap, sehingga kadang-kadang pada saat kepala keluarga tidak bekerja, keluarga tidak memiliki penghasilan, sehingga untuk memenuhi kebutuhan keluarga, contoh terpaksa berhutang ke warung. Tidak ada kepala keluarga yang bekerja sebagai petani, hanya menjadi buruh tani saja diakibatkan minimnya atau tidak adanya lahan pertanian untuk digarap. 
Tabel 6. Sebaran contoh berdasarkan pekerjaan utama dan tambahan kepala keluarga (persentase) pra dan saat PKH

\begin{tabular}{llcccc}
\hline \multirow{2}{*}{ No } & Jenis Pekerjaan Kepala Keluarga & \multicolumn{2}{c}{ Pekerjaan Utama } & \multicolumn{2}{c}{ Pekerjaan Tambahan } \\
\cline { 3 - 5 } & & $\begin{array}{c}\text { PraPKH } \\
(\mathbf{n = 1 3 9})^{\mathbf{1}}\end{array}$ & $\begin{array}{c}\text { Saat PKH } \\
(\mathbf{n}=\mathbf{1 3 3})^{\mathbf{2}}\end{array}$ & $\begin{array}{c}\text { PraPKH } \\
(\mathbf{n = 1 3 9})^{\mathbf{1}}\end{array}$ & $\begin{array}{c}\text { Saat PKH } \\
(\mathbf{n}=\mathbf{1 3 3})^{\mathbf{2}}\end{array}$ \\
\hline 1. & Buruh nontani & 43,9 & 43,6 & 3,6 & 3,7 \\
2. & Buruh tani & 31,0 & 31,6 & 3,6 & 4,5 \\
3. & Dagang & 9,4 & 9,0 & 1,4 & 2,3 \\
4. & Becak & 0,8 & 0,8 & 0,0 & 0,0 \\
5. & Guru les/mengaji/menjaga masjid & 0,8 & 0,8 & 1,4 & 1,5 \\
6. & Karyawan swasta & 0,8 & 0,8 & 0,0 & 0,0 \\
7. & Pemulung & 1,4 & 0,8 & 0,8 & 0,8 \\
8. & Penceramah & 0,8 & 0,0 & 0,0 & 0,0 \\
9. & Supir & 5,7 & 5,3 & 0,0 & 0,0 \\
10. & Tidak bekerja & 4,3 & 6,1 & 89,2 & 87,3 \\
11. & Wiraswasta & 1,4 & 1,5 & 0,0 & 0,0 \\
\hline \multicolumn{2}{l}{ Keterangan : ${ }^{1}$ Meninggal/Pisah sebanyak 11 orang: ${ }^{2}$ Meninggal/Pisah sebanyak 17 orang }
\end{tabular}

Hasil penelitian menunjukkan bahwa dalam kondisi praPKH, istri yang mempunyai pekerjaan utama adalah $45,6 \%$ yang mengalami peningkatan menjadi $47 \%$ saat keluarga mendapat dana PKH. Demikian pula untuk pekerjaan tambahan mengalami peningkatan dari $2,7 \%$ praPKH menjadi $4,7 \%$ saat keluarga mendapat dana PKH. Jenis pekerjaan utama terbanyak ditekuni oleh istri adalah sebagai buruh yang termasuk pekerjaan sporadis apakah menjadi buruh tani, pembantu rumah tangga, ataupun buruh tani (Tabel 7).

Saat mendapatkan dana $\mathrm{PKH}$, secara umum sebagian besar (92,5\%) kepala keluarga tetap dengan pekerjaan utama yang sama dengan $\mathrm{praPKH}$, demikian pula dengan pekerjaan tambahan dimana $86,5 \%$ kepala keluarga tetap tidak mempunyai pekerjaan tambahan saat mendapat dana PKH (Tabel 7). Terdapat 3,8\% kepala keluarga yang tidak bekerja baik sebelum maupun saat mendapat dana PKH. Di lain pihak, sebanyak $48,3 \%$ istri tetap tidak bekerja saat mendapat dana PKH dan 40,9\% tetap dengan pekerjaan yang sama. Peran istri dalam mendukung kepala keluarga memberikan tambahan pendapatan sejalan dengan studi Widyanti et al. (2009) yang menyatakan bahwa bertambahnya orang dewasa yang bekerja dalam rumah tangga akan sangat berpengaruh positif terhadap kapasitas dan kondisi ekonomi melalui penambahan pendapatan rumah tangga.

Menurut Ferro dan Nicollela (2007), secara teori, program CCT dapat mempengaruhi keputusan alokasi waktu untuk seluruh anggota keluarga, karena orangtua sekarang memperoleh uang untuk membeli barang dan mendapat pelayanan untuk keluarga. Aspek lain dari keputusan bekerja dan program transfer tunai adalah bahwa ketika status ekonomi keluarga meningkat dengan alasan apapun dapat mengakibatkan keluarga tidak memenuhi syarat lagi untuk menerima CCT. Secara khusus, jika anggota keluarga bekerja lebih banyak, akan diperoleh cukup uang yang dapat mempe-

Tabel 7. Sebaran contoh berdasarkan pekerjaan utama dan tambahan istri (persentase) pra dan saat $\mathrm{PKH}$

\begin{tabular}{llcccc}
\hline & \multirow{2}{*}{ No } & Jenis Pekerjaan Istri & \multicolumn{2}{c}{ Pekerjaan Utama } & \multicolumn{2}{c}{ Pekerjaan Tambahan } \\
\cline { 3 - 6 } & & $\begin{array}{c}\text { PraPKH } \\
(\mathbf{n = 1 4 9})^{\mathbf{1}}\end{array}$ & $\begin{array}{c}\text { Saat PKH } \\
(\mathbf{n = 1 4 9 )}\end{array}$ & $\begin{array}{c}\text { PraPKH } \\
(\mathbf{n = 1 4 9})^{\mathbf{1}}\end{array}$ & $\begin{array}{c}\text { Saat PKH } \\
(\mathbf{n = 1 4 9})^{\mathbf{1}}\end{array}$ \\
\hline 1. & Buruh tani & 19,4 & 19,4 & 0,7 & 0,7 \\
2. & Buruh nontani & 7,3 & 10,1 & 1,3 & 2,0 \\
3. & Dagang & 4,7 & 4,0 & 0,7 & 1,3 \\
4. & Karyawan swasta & 0,7 & 0,7 & 0,0 & 0,0 \\
5. & Maro kambing & 0,7 & 1,3 & 0,0 & 0,7 \\
6. & Pemulung & 0,0 & 0,7 & 0,0 & 0,0 \\
7. & Penyanyi & 0,7 & 0,7 & 0,0 & 0,0 \\
8. & Pembantu RT & 12,1 & 10,1 & 0,0 & 0,0 \\
9. & Tidak bekerja & 54,4 & 53,0 & 97,2 & 95,3 \\
\hline
\end{tabular}

Ket : ${ }^{1}$ Pisah sebanyak 1 orang 
ngaruhi eligibilitasnya dalam program. Dalam menghadapi kemungkinan ini, orangtua dapat memilih untuk mengurangi pekerjaan sehingga akan terus memperoleh uang transfer. Jika dikaitkan pernyataan tersebut dengan penelitian ini, orangtua yang memperoleh $\mathrm{PKH}$ dapat saja menjadi tidak bekerja karena telah adanya dana $\mathrm{PKH}$. Jika dilihat pada Tabel 8, persentase kepala keluarga yang dari bekerja menjadi tidak bekerja adalah relatif kecil yakni 2,3\%. Sebanyak $4,7 \%$ istri berubah dari bekerja menjadi tidak bekerja. Sayangnya, dalam pengambilan data tidak ditanyakan lebih jauh apakah tidak bekerjanya istri adalah karena telah mendapat dana PKH.

Masyarakat miskin umumnya menghadapi permasalahan terbatasnya kesempatan kerja dan berusaha, terbatasnya peluang mengembangkan usaha, lemahnya perlindungan terhadap aset usaha, dan perbedaan upah serta lemahnya perlindungan kerja terutama bagi pekerja anak dan pekerja perempuan seperti buruh migran perempuan dan pembantu rumah tangga. Keterbatasan modal, kurangnya keterampilan dan pengetahuan, menyebabkan masyarakat miskin hanya memiliki sedikit pilihan pekerjaan yang layak dan peluang yang sempit untuk mengembangkan usaha. Terbatasnya lapangan pekerjaan yang tersedia saat ini seringkali menyebabkan keluarga terpaksa melakukan pekerjaan yang berisiko tinggi dengan imbalan yang kurang memadai dan tidak ada kepastian akan keberlanjutannya. Etos kerja keras yang kurang juga dapat menjadi penyebab rendahnya pendapatan keluarga miskin, yang tergambar pula dari sebagian besar kepala keluarga tidak memiliki pekerjaan sampingan.

Penerimaan Total Keluarga. Penerimaan total keluarga (revenue) merupakan semua pemasukan uang yang diterima oleh keluarga baik yang berasal dari pendapatan (diperoleh dari pekerjaan yang dilakukan untuk mencari nafkah) anggota keluarga maupun sumber-sumber lain seperti pinjaman, dan bantuan dari kerabat atau pemerintah, termasuk dana $\mathrm{PKH}$. Hasil pada Tabel 9 menunjukkan bahwa rata-rata penerimaan total keluarga contoh per bulan per kapita adalah $\mathrm{Rp} 89.594,01$ praPKH dan Rp 118.044,96 saat PKH. Hal ini berarti

Tabel 8. Sebaran contoh berdasarkan perubahan pekerjaan utama dan tambahan kepala keluarga dan istrisaat $\mathrm{PKH}$

\begin{tabular}{|c|c|c|c|c|c|}
\hline \multirow{2}{*}{ No } & \multirow{2}{*}{$\begin{array}{c}\text { Perubahan Kerja } \\
\text { Kepala Keluarga dan Istri }\end{array}$} & \multicolumn{2}{|c|}{ Pekerjaan Utama } & \multicolumn{2}{|c|}{ Pekerjaan Tambahan } \\
\hline & & $\mathbf{n}$ & $\%$ & $\mathbf{n}$ & $\%$ \\
\hline \multicolumn{6}{|c|}{${\text { Perubahan Kerja Kepala keluarga }(n=133)^{1}}^{1}$} \\
\hline 1. & Tetap bekerja & 123 & 92,5 & 14 & 10,5 \\
\hline 2. & Bekerja menjadi tidak bekerja & 3 & 2,3 & 1 & 0,8 \\
\hline 3. & Tidak bekerja menjadi bekerja & 2 & 1,5 & 3 & 2,3 \\
\hline & Tetap tidak bekerja & 5 & 3,8 & 115 & 86,5 \\
\hline \multicolumn{6}{|c|}{ Perubahan Kerja Istri $(n=149)^{2}$} \\
\hline 1. & Tetap bekerja & 61 & 40,9 & 3 & 2,0 \\
\hline 2. & Bekerja menjadi tidak bekerja & 7 & 4,7 & 1 & 0,7 \\
\hline 3. & Tidak bekerja menjadi bekerja & 9 & 6,0 & 4 & 2,7 \\
\hline 4. & Tetap tidak bekerja & 72 & 48,3 & 141 & 94,6 \\
\hline
\end{tabular}

Tabel 9. Sebaran dan statistik penerimaan total keluarga (Rp/kapita/bulan) pra dan saat PKH

\begin{tabular}{|c|c|c|c|c|c|}
\hline \multirow{2}{*}{ No } & \multirow{2}{*}{ Kategori Penerimaan Total Keluarga (Rp) } & \multicolumn{2}{|c|}{ PraPKH $(n=150)$} & \multicolumn{2}{|c|}{ SaatPKH $(n=150)$} \\
\hline & & $n$ & $\%$ & $n$ & $\%$ \\
\hline 1. & Miskin & 124 & 82,7 & 125 & 83,3 \\
\hline 2. & Hampir miskin & 15 & 10,0 & 14 & 9,3 \\
\hline 3. & Hampir tidak miskin & 8 & 5,3 & 7 & 4,7 \\
\hline 4. & Tidak miskin & 3 & 2,0 & 4 & 2,7 \\
\hline \multicolumn{2}{|r|}{ Rata-rata $\pm S D$} & \multicolumn{2}{|c|}{$89.594,01 \pm 55.982,34$} & \multicolumn{2}{|c|}{$118.044,96 \pm 60.567,63$} \\
\hline \multicolumn{2}{|r|}{ Kisaran (min-max) } & 10.000 & $.000,00$ & \multicolumn{2}{|c|}{$22.229,00-365.833,00$} \\
\hline \multicolumn{2}{|r|}{ Uji Beda Berpasangan (sig) } & \multicolumn{4}{|c|}{$0,000^{\star *}$} \\
\hline Ket & $\begin{array}{l}\text { antuk PraPKH digunakan Garis Kemiskinan (GK) wila } \\
\text { Rp144.204,00, sedangkan untuk saatPKH digunakan } 9 \\
\text { tahun } 2009 \text { sebesar Rp175.193,00 } \\
\text { benggunakan kriteria dari Berita Resmi Statistik No. } 4 \\
\text { Kemiskinan). Hampir Miskin : } 1,00-1,25 \text { GK. Hampir Ti }\end{array}$ & $\begin{array}{l}n \text { keluarg } \\
\text { s kemisk }\end{array}$ & $\begin{array}{l}\text { aan Jawa } \\
\text { yah kelu }\end{array}$ & $\begin{array}{l}\text { at tahun } \\
\text { aperdesa }\end{array}$ & $\begin{array}{l}\text { besar } \\
\text { Barat }\end{array}$ \\
\hline
\end{tabular}


penerimaan keluarga mengalami peningkatan saat keluarga mendapat dana PKH. Analisis statistik uji beda berpasangan antara penerimaan praPKH dan saat $\mathrm{PKH}$ dapat disimpulkan bahwa terdapat perbedaan yang nyata $(p=0,000)$ antara keduanya. Hal ini berarti, terjadi peningkatan yang cukup signifikan dalam penerimaan total keluarga contoh saat keluarga mendapat dana PKH. Dengan adanya penambahan penerimaan keluarga dari $\mathrm{PKH}$, maka diperoleh rata-rata penerimaan per kapita sebesar 1,3 kali lipat dari penerimaan praPKH. Program CCT mampu meningkatkan pendapatan keluarga miskin dalam waktu singkat dan meningkatkan kapabilitas manusia dalam jangka medium dan panjang (Son 2008).

Hasil kategorisasi penerimaan total keluarga dengan menggunakan standar garis kemiskinan terlihat bahwa sebagian besar keluarga contoh termasuk dalam kategori kurang dari garis kemiskinan (Rp144.204,00 praPKH dan Rp175.193,00 saat $\mathrm{PKH}$ ) atau terkategori miskin. Hampir tidak ada perubahan kategori kemiskinan keluarga penerima $\mathrm{PKH}$ saat mendapat $\mathrm{PKH}$. Persentase keluarga contoh yang miskin praPKH adalah $82,7 \%$, sedangkan saat $\mathrm{PKH}$ sedikit meningkat menjadi $83,3 \%$. Dengan demikian dapat dikatakan bahwa program PKH belum mampu menurunkan proporsi keluarga miskin setelah berjalan satu tahun dengan pencairan pertama bulan Maret 2008 hingga pencairan 10 April 2009. Temuan penelitian ini masih jauh dari capaian program sejenis di Kolombia yang mampu menurunkan angka kemiskinan hingga $6 \%$. Dampak CCT terhadap kemiskinan bervariasi oleh program, dengan Progresa memberikan hasil yang paling signifikan. Bourguignon et al. (2002) menemukan dampak yang sangat kecil terhadap kemiskinan dan ketidaksetaraan untuk Bolsa Escola karena jumlah transfer yang kecil. Zepeda (2006) juga menyimpulkan bahwa Program CCT memberikan perbedaan besar pada pendapatan rumah tangga miskin, namun tidak mengurangi kemiskinan secara signifikan.

Temuan ini sejalan dengan hasil survei Bappenas (2008) yang mengindikasikan bahwa Program Keluarga Harapan dianggap berpengaruh positif terhadap sensitivitas rumah tangga miskin untuk tumbuh dengan meningkatkan pendapatan dan meningkatkan peluang penghasilan. Dalam jangka panjang, inisiatif pendidikan, dan kesehatan akan berdampak pada generasi berikutnya.
Untuk jangka pendek, $\mathrm{PKH}$ dapat mendorong keluarga untuk berinvestasi paling tidak dari sebagian uang yang diterimanya pada aktivitas yang produktif, sehingga $\mathrm{PKH}$ akan mampu meningkatkan penerimaan total keluarga.

Kriteria miskin kedua yang digunakan adalah Bank Dunia yang mengkategorikan tingkat kemiskinan berdasarkan pendapatan per kapita per hari. Ada dua ukuran yang digunakan, yaitu: (1) US\$ 1 per kapita per hari; dan (2) US\$ 2 per kapita per hari. Dengan menggunakan nilai kurs dari Bank Indonesia per tanggal 10 Agustus 2009, yakni sebesar Rp 9.920,00 untuk US\$1, maka garis kemiskinan Bank Dunia adalah Rp 297.600,00 dan untuk US\$ 2 maka garis kemiskinan Bank Dunia adalah Rp 595.200,00. Menurut garis kemiskinan Bank Dunia US\$ 1 per kapita per hari, persentase keluarga contoh yang tergolong miskin adalah $99,3 \%$ praPKH dan $98,7 \%$ saat $\mathrm{PKH}$, sedangkan menurut garis kemiskinan Bank Dunia US\$2 per kapita per hari, baik pra maupun saat PKH semua keluarga contoh adalah termasuk miskin.

Kemiskinan yang dialami oleh keluarga contoh secara umum menurut Sumodiningrat et al. (1999) dapat dikelompokkan dalam kemiskinan kultural yang lebih berakar pada faktor-faktor budaya setempat (lokal) dan golongan masyarakat tertentu. Sifat kemiskinan kultural lebih banyak diwarnai oleh sikap dan cara pandang individu serta kelompok masyarakat tertentu terhadap kehidupan. Sikap-sikap itu antara lain tercermin dalam watak yang cenderung fatalistik, "nrimo", dan kurang berorientasi ekonomi. Kegiatan ekonomi lebih dipandang sebagai cara untuk memenuhi kebutuhan subsistensi saja dan bukan untuk memupuk kapital. Tidak jarang kegiatan ekonomi dipandang sebagai bagian dari "keserakahan hidup". Dengan cara pandang yang semacam itu, maka secara turun temurun mewariskan kemiskinan kultur pada generasi berikutnya, sehingga "lingkaran kemiskinan" terus membelit karena justru lebih merasa "adjusted" dengan lingkungan (budaya) semacam itu sehingga agak sulit atau memerlukan waktu cukup lama untuk mengubahnya, baik itu lewat pendidikan maupun proses pembangunan yang secara nyata dalam jangka panjang kelak akan membawa dampak perubahan visi.

\section{Kontribusi Anggota Keluarga} terhadap Penerimaan Total Keluarga. Hasil penelitian mengindikasikan bahwa 
kepala keluarga mempunyai kontribusi terbesar $(68,3 \%$ praPKH; $51,1 \%$ saat $\mathrm{PKH})$ terhadap penerimaan total keluarga (Tabel 10 ), baik pra maupun saat $\mathrm{PKH}$, serta secara statistik adalah berbeda nyata $(p=0,008)$. Kontribusi penerimaan total keluarga selanjutnya adalah dari istri yang menyumbang $18,7 \%$ praPKH dan $14,5 \%$ saat $\mathrm{PKH}$.

Anggota keluarga lain yang menyumbang terhadap penerimaan keluarga adalah anak $(10,6 \%$ praPKH; $9,9 \%$ saat $\mathrm{PKH})$ dan pemasukan lain $(2,5 \%$ praPKH; $2,1 \%$ saat $\mathrm{PKH}$ ). Baik kontribusi istri, anak maupun anggota keluarga lain tidak menunjukkan perbedaan yang nyata antara pra dan saat $\mathrm{PKH}$. Kontribusi dana PKH terhadap penerimaan total keluarga adalah sebesar $22,4 \%$, sehingga kontribusi anggota keluarga menjadi berkurang dari praPKH. Hal ini sejalan dengan skenario bantuan $\mathrm{PKH}$ yang diperkirakan menyumbang antara $15-25 \%$ terhadap pendapatan rata-rata RTSM per tahun.

Pengeluaran Total Keluarga. Pengeluaran rata-rata per kapita per bulan adalah biaya yang dikeluarkan untuk semua anggota rumah tangga selama sebulan dibagi dengan banyaknya anggota rumah tangga. Tabel 11 menunjukkan bahwa pengeluaran rata-rata per bulan keluarga contoh mempunyai persentase terbesar untuk pengeluaran pangan per bulan $(70,1 \%)$ yang jauh lebih besar daripada rata-rata pengeluaran nonpangan per bulan $(29,9 \%)$. Hal ini sejalan dengan Soekirman (1991) yang menyatakan bahwa keluarga berpendapatan rendah di Indonesia membelanjakan sekitar 60 hingga $80 \%$ dari pendapatannya untuk memenuhi kebutuhan pangan. Hal ini juga senada dengan Suhardjo (1989) bahwa golongan miskin menggunakan bagian terbesar dari pendapatannya untuk memenuhi kebutuhan makanan.

Keluarga contoh rata-rata mengalokasikan pengeluaran untuk pangan per kapita per bulan sebesar Rp 141.892,16 dan alokasi pengeluaran untuk nonpangan ratarata sebesar $\mathrm{Rp} 60.405,91$ per kapita perbulan. Berarti total pengeluaran yang dialokasikan untuk pangan adalah sekitar 2,3 kali lebih besar dibandingkan untuk

Tabel 10. Kontribusi anggota keluarga dan pemasukan lainnya terhadap rata-rata penerimaan total keluarga (Rp/bulan) pra dan saat PKH

\begin{tabular}{llrrrrr}
\hline \multirow{2}{*}{ No } & \multicolumn{1}{c}{ Kontributor } & \multicolumn{2}{c}{ PraPKH(n=150) } & \multicolumn{2}{c}{ SaatPKH (n=150) } & \multirow{2}{*}{ Uji Beda (t-test) } \\
\cline { 3 - 6 } & & Rata-Rata & \% & Rata-Rata & \% & $0,008^{* *}$ \\
1. & Kepala keluarga & $302.741,33$ & 68,3 & $301.744,67$ & 51,1 & 0,157 \\
2. & Istri & $82.873,33$ & 18,7 & $85.536,00$ & 14,5 & 0,323 \\
3. & Anak & $46.930,00$ & 10,6 & $58.363,33$ & 9,9 & 0,313 \\
4. & Pemasukan lainnya & $10.939,60$ & 2,5 & $12.684,56$ & 2,1 & 22,4 \\
5. & Dana PKH & - & & $132.207,78$ & 100,0 & \\
6. & Penerimaan total & $443.484,26$ & & $590.536,34$ & &
\end{tabular}

Tabel 11. Statistik dan rata-rata pengeluaran keluarga (Rp/kapita/bulan) berdasarkan kategori kemiskinan penerimaan total keluarga

\begin{tabular}{|c|c|c|c|c|}
\hline No & $\begin{array}{c}\text { Kategori Kemiskinan } \\
\text { Penerimaan Total Keluarga }^{\text {ab }}\end{array}$ & Pangan & Nonpangan & Pengeluaran Total \\
\hline 1. & Miskin & $135.676,22$ & $56.726,00$ & $192.402,22$ \\
\hline 2. & Hampir miskin & $189.623,97$ & $70.862,82$ & $260.486,79$ \\
\hline 3. & Hampir tidak miskin & $148.286,19$ & $91.143,81$ & $239.430,00$ \\
\hline 4. & Tidak miskin & $157.889,58$ & $85.012,92$ & $242.902,50$ \\
\hline 5. & Total & $141.892,16$ & $60.405,91$ & $202.298,08$ \\
\hline & Rata-rata & $141.892,16$ & $60.405,91$ & $202.298,08$ \\
\hline & Standar deviasi & $59.011,50$ & $34.490,82$ & $76.891,27$ \\
\hline & Nilai minimum & $40.111,11$ & $12.666,67$ & $70.166,67$ \\
\hline & Nilai maksimum & $466.750,00$ & $203.202,78$ & $627.250,00$ \\
\hline & $\%$ terhadappengeluaran total & 70,1 & 29,9 & 100,00 \\
\hline
\end{tabular}


pengeluaran nonpangan. Teori Ernst Engel juga mendukung hasil temuan penelitian, yakni proporsi pengeluaran total untuk makanan menurun dengan meningkatnya pendapatan. Pola pengeluaran rumah tangga dapat mencerminkan tingkat kehidupan suatu masyarakat. Indikator yang dipakai untuk mengukur tingkat kesejahteraan penduduk adalah komposisi pengeluaran untuk makanan dan nonmakanan. Kesejahteraan dikatakan makin baik bila persentase pengeluaran untuk makanan semakin kecil.

Rata-rata pengeluaran per kapita per bulan keluarga sebesar Rp 202.298,08, yang berkisar antara Rp 70.166,67 hingga Rp 627.250,00. Jika dibandingkan dengan penerimaan total keluarga, maka pengeluaran keluarga hampir tiga kali lipat lebih besar. Hal ini dapat terjadi karena bertambahnya penerimaan keluarga dari dana PKH. Hall (2006) menyatakan bahwa bukti dari program CCT di Amerika Latin menunjukkan hasil positif yang dapat dicapai terkait dengan pemenuhan kebutuhan mendesak dari keluarga miskin.

Kepemilikan Aset. Rumah merupakan salah satu kebutuhan penting bagi setiap keluarga. Lebih dari tiga perlima $(66,7 \%)$ kepemilikan rumah keluarga contoh adalah rumah sendiri (Tabel 12), diikuti oleh rumah milik orangtua/keluarga $(32,7 \%)$ dan kontrak/sewa $(0,7 \%)$.

Tabel 12.Sebaran dan statistik status kepemilikan rumah dan luas rumah

\begin{tabular}{|c|c|c|c|}
\hline No & $\begin{array}{l}\text { Status Kepemilikan } \\
\text { dan Luas Rumah }\end{array}$ & $\begin{array}{c}\text { Jumlah } \\
(\mathrm{n})\end{array}$ & $\begin{array}{c}\text { Persentase } \\
(\%)\end{array}$ \\
\hline \multicolumn{4}{|c|}{ Status kepemilikan rumah $(n=150)$} \\
\hline 1. & Sendiri & 100 & 66,7 \\
\hline 2. & Kontrak/Sewa & 1 & 0,7 \\
\hline 3. & Milik Orangtua/Keluarga & 49 & 32,7 \\
\hline \multicolumn{4}{|c|}{ Kategori luas rumah per kapita $(n=150)$} \\
\hline 1. & $<8 \mathrm{~m}^{2}$ & 91 & 60,7 \\
\hline & $>8 \mathrm{~m}^{2}$ & 59 & 39,3 \\
\hline & Rata-Rata $\pm S D$ & \multicolumn{2}{|c|}{$7,69 \pm 5,25$} \\
\hline & Kisaran (min-max) & \multicolumn{2}{|c|}{$1,00-33,33$} \\
\hline
\end{tabular}

Rata-rata luas rumah per kapita keluarga adalah $7,69 \mathrm{~m}^{2}$ dengan persentase keluarga yang memiliki rumah dengan luas kurang dari $8 \mathrm{~m}^{2}$ adalah sebanyak $60,7 \%$ serta berkisar antara $1 \mathrm{~m}^{2}$ hingga $33,33 \mathrm{~m}^{2}$ per kapita. Data ini menunjukkan masih kurang sehatnya rumah yang dihuni karena tidak sesuai dengan batas yang disebut rumah sehat, dan selain itu rumah yang sempit juga memunculkan ketidaknyamanan penghuninya. Rumah dengan luas yang cukup merupakan prasyarat penting untuk menunjang kehidupan yang sejahtera. Rumah sehat menurut World Health Organization adalah rumah yang memiliki luas lantai minimal $10 \mathrm{~m}^{2}$ per kapita. Menurut Departemen Kesehatan (BKKBN 2001) luas lantai rumah merupakan indikator kesejahteraan ekonomi yang dapat dilihat secara fisik dengan kriteria miskin jika luas lantai kurang atau sama dengan $8 \mathrm{~m}^{2}$ per kapita dan tidak miskin jika lebih dari $8 \mathrm{~m}^{2}$ per kapita.

Aset adalah salah satu bentuk sumberdaya materi yang dimiliki keluarga yang dapat digunakan untuk mencapai tujuan yang diharapkan oleh keluarga tersebut (Raines 1964). Secara umum aset keluarga dalam penelitian ini dikelompokkan menjadi lima, yaitu kendaraan, ternak, alat elektronik, alat RT, dan kepemilikan mebel (Tabel 13). Kepemilikan kendaraan berupa motor atau sepeda sangat sedikit ditemukan pada keluarga contoh, motor hanya dimiliki oleh $2 \%$ keluarga contoh. Secara umum, kepemilikan ternak pada keluarga contoh

Tabel 13.Sebaran contoh berdasarkan kepemilikan aset pra dan saat PKH (persentase)

\begin{tabular}{|c|c|c|c|c|}
\hline No & Jenis Aset & $\begin{array}{l}\text { PraPKH } \\
(n=150)\end{array}$ & $\begin{array}{c}\text { Saat PKH } \\
(n=150)\end{array}$ & Delta \\
\hline \multicolumn{5}{|c|}{ Kepemilikan Kendaraan } \\
\hline 1. & Motor & 2,0 & 2,0 & 0,0 \\
\hline 2. & Sepeda & 12,0 & 12,7 & 0,7 \\
\hline \multicolumn{5}{|c|}{ Kepemilikan Ternak } \\
\hline 1. & $\begin{array}{l}\text { Kambing/domba } \\
\text { (induk/anak) }\end{array}$ & 12,0 & 12,0 & 0,0 \\
\hline 2. & Ayam & 24,7 & 30,7 & 6,0 \\
\hline 3. & Itik & 3,3 & 4,7 & 1,4 \\
\hline 4. & Kelinci & 0,0 & 1,3 & 1,3 \\
\hline 5. & Ikan & 1,3 & 3,3 & 2,0 \\
\hline 6. & Angsa & 0,0 & 0,7 & 0,7 \\
\hline 7. & Bebek & 1,3 & 2,0 & 0,7 \\
\hline \multicolumn{5}{|c|}{ Kepemilikan Alat Elektronik } \\
\hline 1. & Radio/Tape & 22,0 & 21,3 & $-0,7$ \\
\hline 2. & Video/CD & 9,3 & 12,0 & 2,7 \\
\hline 3. & Kipas angin & 5,3 & 4,7 & $-0,6$ \\
\hline 4. & $\mathrm{HP}$ & 5,3 & 13,3 & 8,0 \\
\hline 5. & Televisi & 49,3 & 50,7 & 1,4 \\
\hline 6. & Setrika listrik & 35,3 & 20,7 & $-14,6$ \\
\hline 7. & Kulkas & 1,3 & 2,7 & 1,4 \\
\hline 8. & Dispenser & 2,0 & 6,0 & 4,0 \\
\hline 9. & Rice Cooker & 6,7 & 10,7 & 4,0 \\
\hline \multicolumn{5}{|c|}{ Kepemilikan Alat RT } \\
\hline 1. & Lemari makan & 7,3 & 6,7 & $-0,6$ \\
\hline 2. & Oven & 2,7 & 2,7 & 0,0 \\
\hline 3. & Mesin jahit & 2,0 & 2,7 & 0,7 \\
\hline 4. & Kompor gas & 10,0 & 70,7 & 60,7 \\
\hline 5. & Kompor minyak & 48,0 & 32,0 & $-16,0$ \\
\hline \multicolumn{5}{|c|}{ Kepemilikan Mebel } \\
\hline 1. & Kursi tamu (set) & 14,0 & 12,7 & $-1,3$ \\
\hline 2. & Meja makan (set) & 6,0 & 5,3 & $-0,7$ \\
\hline 3. & Tempat tidur & 72,7 & 70,3 & $-2,4$ \\
\hline 4. & Lemari pakaian & 72,0 & 71,3 & $-0,7$ \\
\hline 5. & Lemari hias & 2,0 & 2,0 & 0,0 \\
\hline 6. & Lemari buku & 2,0 & 2,0 & 0,0 \\
\hline
\end{tabular}


mengalami peningkatan, meskipun tidak terlalu besar, namun sebagian besar keluarga contoh tidak memiliki ternak. Alat elektronik yang terbanyak dimiliki oleh sekitar setengah keluarga contoh adalah televisi. Terdapat beberapa alat elektronik yang persentase kepemilikannya meningkat saat mendapat dana $\mathrm{PKH}$, seperti video/CD dari $9,3 \%$ praPKH menjadi $12 \%$ saat $\mathrm{PKH}$, HP dari $5,3 \%$ praPKH menjadi $13,3 \%$ saat $\mathrm{PKH}$, televisi dari $49,3 \%$ praPKH menjadi $50,7 \%$ saat $\mathrm{PKH}$, kulkas dari 1,3\% praPKH menjadi $2,7 \%$ saat $\mathrm{PKH}$, dispenser dari $2 \%$ praPKH menjadi $6 \%$ saat $\mathrm{PKH}$, serta rice cooker dari $6,7 \%$ praPKH menjadi $10,7 \%$ saat $\mathrm{PKH}$.

Kepemilikan alat RT hanya meningkat secara signifikan pada kompor gas, yakni dari $10 \%$ praPKH menjadi $70,7 \%$ saat $\mathrm{PKH}$. Hal ini lebih diakibatkan oleh adanya program konversi minyak tanah menjadi gas yang dicanangkan oleh pemerintah dan dibagikan secara gratis kepada masyarakat. Berbanding terbalik dengan kompor gas, kepemilikan kompor minyak justru mengalami penurunan karena semakin banyaknya masyarakat yang melakukan konversi kepada kompor gas.

Kepemilikan mebel secara umum tidak mengalami perubahan pra dan saat mendapat dana PKH. Dengan demikian, secara umum, peningkatan kepemilikan aset saat keluarga mendapat dana $\mathrm{PKH}$ lebih kepada pembelian beberapa alat elektronika. Hal ini menjadi indikasi pola hidup yang konsumtif yang telah menjadi budaya yang melekat pada masyarakat miskin. Contoh sederhana adalah kepemilikan handphone (HP), yang saat ini telah beralih menjadi kebutuhan primer bagi masyarakat dari semua kalangan. Padahal bukan hanya handphone-nya saja yang harus dibeli, namun kebutuhan pulsa juga akan memberatkan pengeluaran keluarga. Temuan penelitian ini sejalan dengan pernyataan De Janvry dan Sadoulet (2005) berdasarkan program CCT di Meksiko dan Brazil bahwa jika dibandingkan dengan program bantuan langsung tunai, maka melalui pendekatan bantuan tunai bersyarat (CCT) dapat dicapai tujuan pendapatan untuk meningkatkan aset dan pendekatan ini sangat efektif.

Rasio Hutang dan Aset. Hal menarik yang perlu dicermati dari data penelitian adalah sebanyak $47,3 \%$ keluarga contoh mengaku memiliki hutang sebelum mendapat dana $\mathrm{PKH}$, yang ternyata mengalami peningkatan menjadi hampir dua kali lipat $(82,7 \%)$ saat mendapat dana PKH (Tabel 14). Hal ini disebabkan adanya pola pikir dikalangan keluarga contoh, nantinya akan mendapat dana $\mathrm{PKH}$ sehingga berhutang atau meminjam uang sebelum dana PKH turun. Apalagi turunnya dana PKH sering mengalami keterlambatan dari informasi tanggal yang sudah direncanakan, sehingga contoh memilih berhutang dahulu terutama untuk menutupi kebutuhan sehari-hari.

Untuk memperoleh data rasio hutang terhadap aset, dalam penelitian ini aset juga dilihat berdasarkan perkiraan nilainya yakni Rp 376.880,00 (Rp 67.378,32) praPKH dan Rp 517.386,67 (Rp95.816,14) saat PKH. Perkiraan nilai aset yang dimiliki keluarga contoh dilakukan dengan mempertimbangkan penyusutan karena usia pakai, harga pembelian dan harga jual saat ini. Sementara hasil wawacara menunjukkan bahwa ratarata hutang keluarga adalah $\mathrm{Rp} 265.522,00$ (Rp 49.009,35 per kapita) praPKH dan Rp 470.362,69 (Rp 87.623,97/kapita) saat $\mathrm{PKH}$.

Tabel 14.Sebaran dan statistik kepemilikan hutang dan rasio hutang dan aset pra dan saat $\mathrm{PKH}$

\begin{tabular}{|c|c|c|c|c|c|}
\hline \multirow{2}{*}{ No } & \multirow{2}{*}{ Kepemilikan Hutang } & \multicolumn{2}{|c|}{ PraPKH (n=150) } & \multicolumn{2}{|c|}{ Saat PKH $(n=150)$} \\
\hline & & $\mathbf{n}$ & $\%$ & $\mathbf{n}$ & $\%$ \\
\hline \multicolumn{6}{|c|}{ Kepemilikan Hutang } \\
\hline 1. & Ya & 71 & 47,3 & 124 & 82,7 \\
\hline 2. & Tidak & 79 & 52,7 & 26 & 17,3 \\
\hline & Rata-Rata $\pm S D(R p)$ & \multicolumn{2}{|c|}{$265.522,00 \pm 845.471,94$} & \multicolumn{2}{|c|}{$470362,69 \pm 1015429,98$} \\
\hline & Kisaran (min-max) (Rp) & \multicolumn{2}{|c|}{$0-5.100 .000$} & \multicolumn{2}{|c|}{$0-5.525 .000$} \\
\hline & ji Beda Berpasangan (sig) & & & & \\
\hline \multicolumn{6}{|c|}{ Kategori Rasio Hutang dan Aset } \\
\hline 1. & $\leq 50 \%$ & 38 & 25,6 & 66 & 43,7 \\
\hline 2. & $>50 \%$ & 112 & 74,4 & 84 & 56,3 \\
\hline
\end{tabular}


Dengan demikian, jika dilihat dari ratarata keseluruhan nilai aset masih lebih tinggi dibandingkan dengan hutang baik pada saat pra maupun saat mendapatkan dana $\mathrm{PKH}$. Namun jika dilihat dari rasio hutang terhadap aset per keluarga (Tabel 14), maka sebelum mendapat dana $\mathrm{PKH}$ rata-rata hutang keluarga contoh sekitar dua pertiga $(74,4 \%)$ termasuk lebih dari 50\%. Saat mendapat dana $\mathrm{PKH}$, rasio hutang terhadap aset mengalami penurunan dimana keluarga dengan rasio lebih dari $50 \%$ menurun menjadi $56,3 \%$. Dengan demikian, kemampuan membayar hutang dengan menggunakan aset yang dimiliki, semakin meningkat dengan diperolehnya dana $\mathrm{PKH}$.

Jika hutang dibandingkan dengan pendapatan, maka diperoleh rata-rata 0,55 praPKH dan 0,92 saat $\mathrm{PKH}$, artinya hutang saat $\mathrm{PKH}$ semakin tidak dapat ditutupi oleh pendapatan. Selanjutnya, jika hutang dibandingkan dengan penerimaan saat $\mathrm{PKH}$ (pendapatan ditambah dana $\mathrm{PKH}$ ), maka kemampuan untuk membayar hutang semakin besar dengan turunnya hampir setengah $(0,49)$ rasio hutang terhadap penerimaan.

\section{KESIMPULAN DAN SARAN}

\section{Kesimpulan}

Karakteristik demografi, sosial, dan ekonomi keluarga contoh yang dapat disimpulkan dari penelitian ini adalah persentase terbesar keluarga berkisar antara 5 hingga 6 orang dengan struktur keluarga adalah keluarga inti, serta usia ayah dan ibu berkisar antara 30 sampai 49 tahun. Tingkat pendidikan ayah dan ibu hanya sampai SD dengan profesi ayah sebagai buruh, sedangkan ibu kebanyakan tidak bekerja. Sebagian besar kepala keluarga dan istri melek aksara baik dari membaca maupun menulis aksara latin. Selain dana $\mathrm{PKH}$, keluarga contoh juga memperoleh bantuan berupa Beras Miskin (Raskin), Askeskin (Asuransi Kesehatan untuk Masyarakat Miskin)/Jamkesmas (Jaminan Kesehatan Masyarakat) atau BLT (Bantuan Langsung Tunai).

Penerimaan total keluarga meningkat secara signifikan 1,3 kali lipat pada saat mendapat PKH. Kategori kemiskinan contoh tidak berubah dengan adanya $\mathrm{PKH}$, namun kepemilikan alat elektronik mengalami peningkatan. Kepala keluarga mempunyai kontribusi terbesar baik praPKH maupun saat $\mathrm{PKH}$ terhadap penerimaan total keluar- ga serta secara statistik adalah berbeda nyata. Pengeluaran rata-rata per bulan keluarga untuk pangan $70,1 \%$ dan nonpangan $29,9 \%$. Terjadi peningkatan yang signifikan menjadi hampir dua kali lipat keluarga yang berhutang saat mendapat dana $\mathrm{PKH}$. Kemampuan membayar hutang dengan aset yang dimiliki, semakin meningkat dengan diperolehnya dana $\mathrm{PKH}$.

\section{Saran}

Berdasarkan kajian karakteristik ekonomi yang mengindikasikan belum adanya perubahan kategori miskin keluarga penerima PKH setelah diluncurkan tahun 2008, maka pemerintah perlu lebih bekerja keras agar program ini tidak mengalami kegagalan sehingga target MDGs tahun 2015 dapat dicapai khususnya untuk pengurangan angka kemiskinan.

Penelitian lanjutan dapat dilakukan dengan membedakan antara kontrol (contoh yang tidak mendapat dana $\mathrm{PKH}$ ) dan perlakuan (keluarga yang mendapat dana $\mathrm{PKH}$ ) sehingga dapat diperoleh perbandingan karakteristik keluarga yang lebih comparable. Dapat juga dilakukan penelitian dengan membedakan lokasi penerima PKH yakni di perkotaan dan perdesaan.

\section{DAFTAR PUSTAKA}

[BAPPENAS] Badan Perencanaan Pembangunan Nasional. 2008. Program Keluarga Harapan-PKH. Two cases studies on implementing the indonesian condition cash transfer program. Working Paper No. 5. Jakarta: The ProPoor Planning and Budgeting Project.

[BKKBN] Badan Kordinasi Keluarga Berencana Nasional. 2001. Indikator Kesejahteraan Keluarga. Jakarta: BKKBN.

[BPS] Badan Pusat Statistik. 2009. Angka Partisipasi Kasar (APK) Menurut Provinsi Tahun 2003-2008. http://www.bps.go.id/tab_sub/view.php?t abel=1\&daftar=1\&id_subyek=28\&notab $=38$ [ 2 Februari 2010].

. 2009. Profil Kemiskinan di Indonesia Maret 2009. Berita Resmi Statistik No. 43/07/Th. XII, 1 Juli 2009. http://www.bps.go.id/brs_file/kemiskinan -01jul09.pdf [15 Desember 2009].

[UNDP] United Nations Development Program. Human Development Report 2009. http://hdr.undp.org/en/statistics/ [11 Januari 2010]. 
Bourguignon F, Ferreira F, Leite P. 2002. Exante Evaluation of Conditional Cash Transfer Programs: The Case of Bolsa Escola. Policy Research Working Paper No. 2916, World Bank, Washington,DC. http://www.wdi.umich.edu/files/Publicati ons/WorkingPapers/wp516.pdf. $[20$ November 2009].

De Janvry A, Sadoulet E. 2005. Conditional Cash Transfer Programs for Child Human Capital Development: Lessons Derived from experience in Mexico and Brazil. University of California at Berkeley and World Bank Development Economics Research Group.http://www.cgdev.org/doc/event \% 20docs/MADS/SAIS-CCT.pdf. November 2009].

Dharmawan et al. 2009. Agenda Riset Strategis Bidang Penanggulangan Kemiskinan 2010 - 2015. Bogor: Institut Pertanian Bogor.

Ferro AR, Nicollela AC. 2007. The Impact of Conditional Cash Transfer Programs on Household Work Decisions in Brazil. March 2007. Center for Advanced Studies on Applied. http://www.iza.org/conference files/worl db2007/ferro_a3468.pdf. [5 Januari 2010].

Gunarsa S, Gunarsa Y. 2008. Psikologi Praktis: Anak, Remaja, dan Keluarga. Jakarta: BPK Gunung Mulia.

Hall A. 2006. Fome Zero to Bolsa Famı'lia: Social Policies and Poverty Alleviation.J. Lat. Amer. Stud. 38:689-709 f 2006 Cambridge University Press.

\footnotetext{
* Korespondensi :

Telp : +62-2518628303

Email : mega_juntak@yahoo.com
}

Raines M. 1964. Managing Livingtime. Illionis: Chas A Bennet Co.Inc.

Soekirman. 1991. Dampak Pembangunan terhadap Keadaan Gizi. Orasi Penerimaan Jabatan Guru Besar Luar Biasa IImu Gizi. Bogor: Fakultas Pertanian, IPB.

Son HH. 2008. Conditional Cash Transfer Programs: An Effective Tool for Poverty Alleviation? Juli 2008. Economics and Research Department ERD Policy Brief Series No. 51. Asian Development Bank. Mandaluyong City. Metro Manila, Philippines. www.adb.org/ economics. [2 Januari 2009].

Suhardjo. 1989. Sosio Budaya Gizi. Bogor: Pusat Antar Universitas, IPB.

Sumodiningrat G, Santosa B, Maiwan M. 1999. Kemiskinan: Teori, Fakta, dan Kebijakan. Jakarta: Impac.

Widyanti W, Suryahadi A, Sumarto S, Yumna A. 2009. The Relationship between Chronic Poverty and Household Dynamics: Evidence from Indonesia/ Jakarta: SMERU Research Institute, 2009. ii, 19 p. ; $30 \mathrm{~cm}$. -- (SMERU Working Paper, January 2009). http://www.chronicpoverty.org/uploads/p ublication files/WP132 WidyantiSuryadehi-Sumarto-Yumna.pdf. $[10$ Januari 2010].

Zepeda E. 2006. Do CCTs Reduce Poverty?, IPC One Pager, No. 21 September 2006. Poverty International Center. United Nations Development Programme (UNDP). http://www.ipcundp.org/pub/IPCOnePager21.pdf. [4 Januari 2010]. 